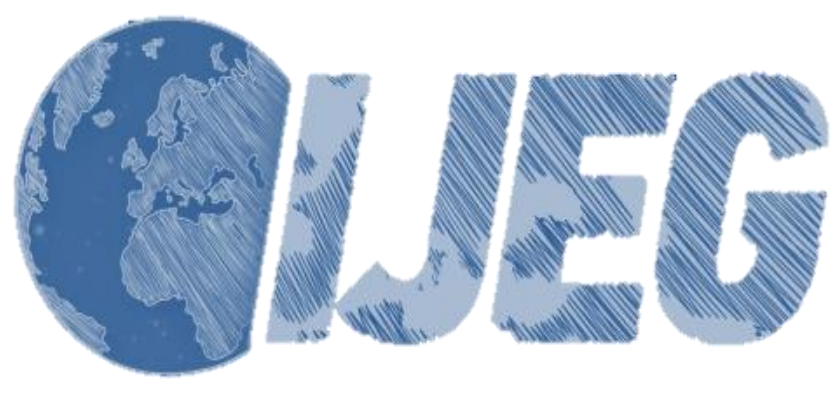

International Journal of Engineering and Geosciences (IJEG),

Vol; 1 , Issue; 01, pp. 1-7, October, 2016, ISSN 2548-0960, Turkey, DOI: Your DOI number

\title{
INVESTIGATION OF THREE-DIMENSIONAL MODELLING AVAILABILITY TAKEN PHOTOGRAPH OF THE UNMANNED AERIAL VEHICLE; SAMPLE OF KANLIDIVANE CHURCH
}

\author{
Ulvi, A., ${ }^{1 *}$ Toprak, A.S., ${ }^{2}$ \\ ${ }^{1}$ SelcukUniversity, Hadim Vocational Schools of Higher Education, Konya, Turkey \\ (aliulvi@ selcuk.edu.tr) \\ ${ }^{2}$ KOP Administration , Konya, Turkey (ahmetsuadtoprak@gmail.com)
}

*Corresponding Author, Received: 01/06/2016, Accepted: 15/07/2016

\begin{abstract}
Cultural heritages due to have different natural characteristics, have different sizes, and heir complicated structure should be measured and requires a more sophisticated measurement tools and techniques to documentation. One of them aerial photos taken by UAV pictures to use in architectural photogrammetry.In this study, Photogrammetric study was conducted in the ancient church next to the pothole. The study was completed with photographs taken from the air with UAV and close range photogrammetry. The images obtained from both methods adjusted in photogrammetric software and obtained a three-dimensional model of the church. Photography by UAV has proved to be a technical supporters of close range photogrammetry. Also coordinates of the reference points on the images obtained through photogrammetric software and compared with terrain coordinates. Point position accuracy of points $\mathrm{mxyz}=2.1 \mathrm{~cm}$ were found. In order to protect the world heritage of cultural heritage IHA help to be sensitive enough to measure derived from aerial photographs taken, can be used as a base to work from different professional disciplines, The UAV was concluded in anywhere near the height can be used for photogrammetric.
\end{abstract}

Keywords: UAV Photogrammetry, Precision,3D model 


\section{INTRODUCTION}

In many of cultural heritage documentation work could not be registered for reasons such as the lack of, cost, technology insufficieny, qualified staff and time constraints. (Hunt et al from., 2014).Although Turkey is an important country in terms of archaeological and cultural heritage, the lack of efficient work in the field work or be very limited,of the studies can not always be carried out with sufficient accuracy and lack of documentation however, due to a misunderstanding of the scope,not being able pass on to future generations is in danger. This troubled situation of new technologies in order to produce solutions in this area in order to prove the availability of terrestrial laser scanning technology and Unmanned Aerial Vehicle (UAV) is used in this context. Cultural heritage of different natural features, are required to have a different size and detail can be measured due to the complex and sophisticated measuring tools and techniques to document. One of them is the Unmanned Aerial Vehicle (UAV) technology.

\subsection{Unmanned aerial vehicles (UAV)}

UAV's can be defined as fixed and rotary wing aircraft which is on the fly without a human being (Eroglu, 2013). These vehicles by remote control, semiautomatic, automatic, or have all of these capabilities (EISENBEISS, 2009). The academic resources were analyzed, we come across dozens of similar statements about the UAV. They are also considering unmanned aerial vehicles (UAVs) could make the definition as follows: Which can be controlled from the ground, flight planning capabilities which, with fixed or rotary wing, military and used in civilian areas on a pilot system for non Unmanned Aerial Vehicle (UAV) is called

\subsection{UAV Benefits}

Against manned system, The biggest advantage of UAVs; UAV in risky situations without risking human life and inaccessible areas of the low-altitude flight profile and it is close to the ends of the object and can not be used in place manned system.

For example, natural disaster areas, mountainous and volcanic areas, flood plains, earthquake and accident scenes and desert areas, areas that are difficult to enter, are used. (Ulvi A., 2015)

In addition to these advantages, the mapping activities and architectural applications, and are also used frequently in archaeological sites.

\section{STUDY AREA}

Kanlidivane is in the rural area of Erdemli district, which is a part of Mersin Province. It is $18 \mathrm{~km}(11 \mathrm{mi})$ to Erdemli and $55 \mathrm{~km}$ (34 mi) to Mersin. Its altitude is approximately $230 \mathrm{~m}(750 \mathrm{ft})$. It is close to the town Kumkuyu at the coast and just few hundred meters to Çanakçı rock tombs.Kanytelleis-Kanlıdivane ruins Mersin-Silifke highway since the 50th $\mathrm{km}$, the resort is located $3 \mathrm{~km}$ north of Ayas. The first settlement on the ruins of the old name Kanytelleis BC It was built in the late 3rd century. A tower of the period to the Hellenistic city has kept its existence until the 11th century."Kanl1Bloody Divane", the pothole within the city, former offenders, among the people because of the belief that gnawed by wild animals, as is known. The church is next to the pothole (Figure 1).

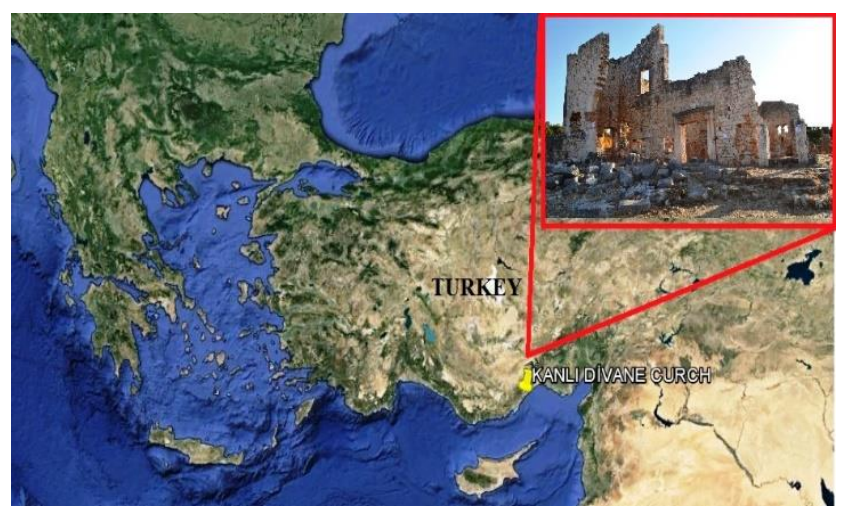

Figure 1. Kanlidivane Church overview

\section{MATERIAL METHOD}

\subsection{Pre-work preparation}

Used in the application $\mathrm{H}$ (Figure 2), digital camera (figure 3), total station (Figure 4) and a ground control plates used in the evaluation of the photograph obtained from the UAV (Figure 5), paper targets affixed to the wall (Figure 6) and the image transmission system, (Figure 7) are provided.

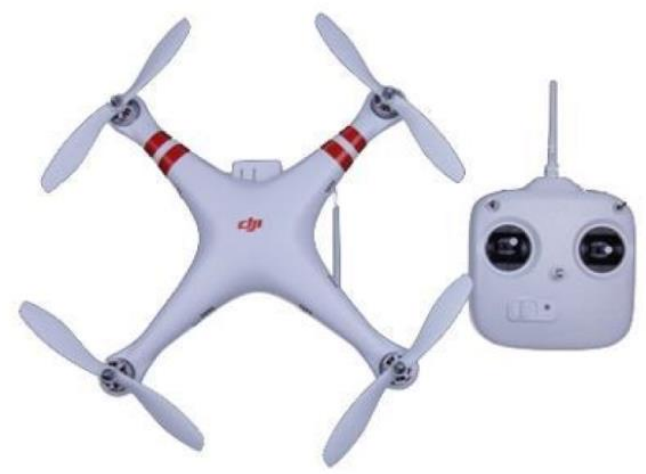

Figure 2. DJI Phantom UAV

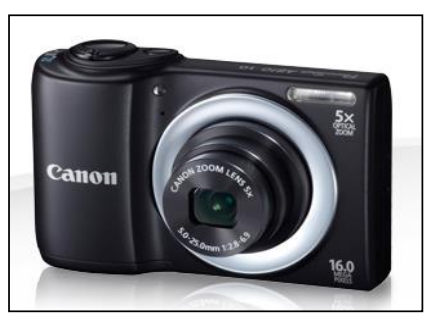

Figure 3. Canon PowerShot A810 
International Journal of Engineering and Geosciences (IJEG),

Vol; 1; , Issue; 01, pp. 1-7, December, 2016,

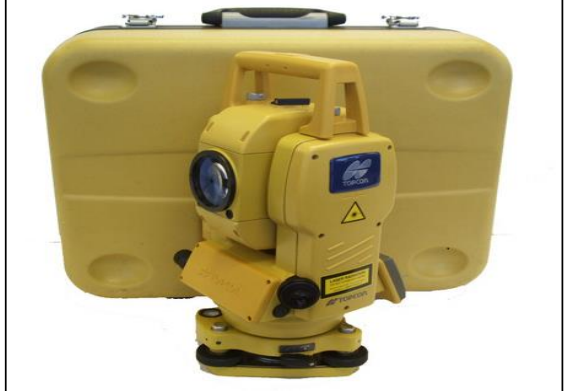

Figure 4.Total Station Topcon GPT 3007

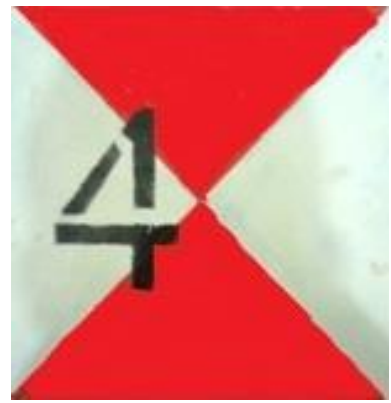

Figure 5.Graund Control Point

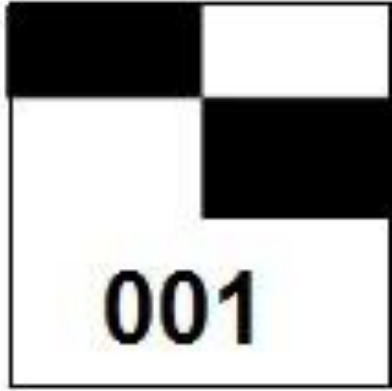

Figure 6.Target

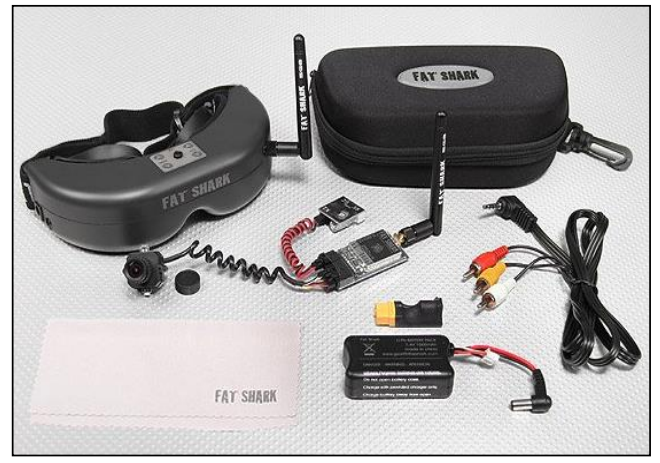

Figure 7. FatShark

\subsection{Field study}

Ground control points have been established as a homogeneous field in the application (Figure 8).In this application 8 Ground control points has been installed.While for establishment of ground control points, point of care has been taken to distribute to completely cover the work area and to see each other.

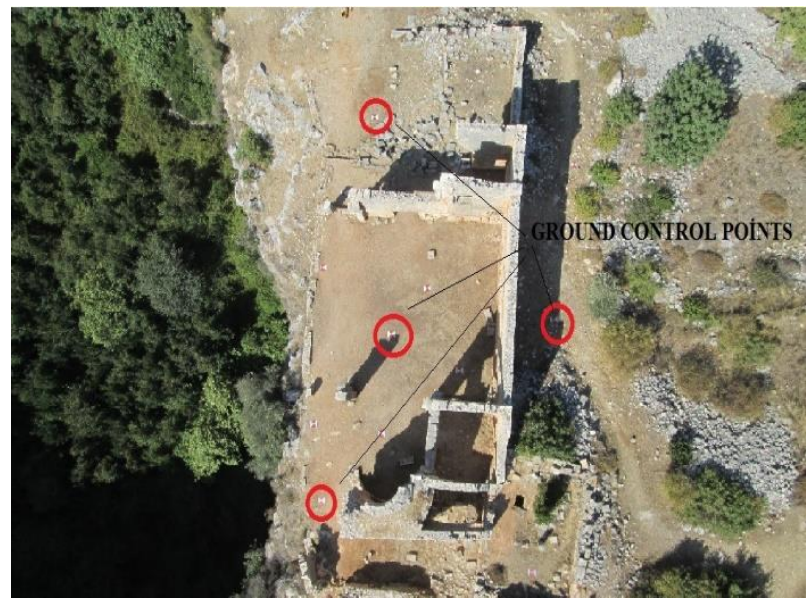

Figure 8. Distribution of ground control points in field

Georeferencing operation of ground control points were made by Topcon GPT 3007 reflectorless total station (Figure 9).

Around of applications, making closed traverse was calculated coordinates of ground control points.ground control and coordinates of the feature point is measured in the local system (Figure 10).

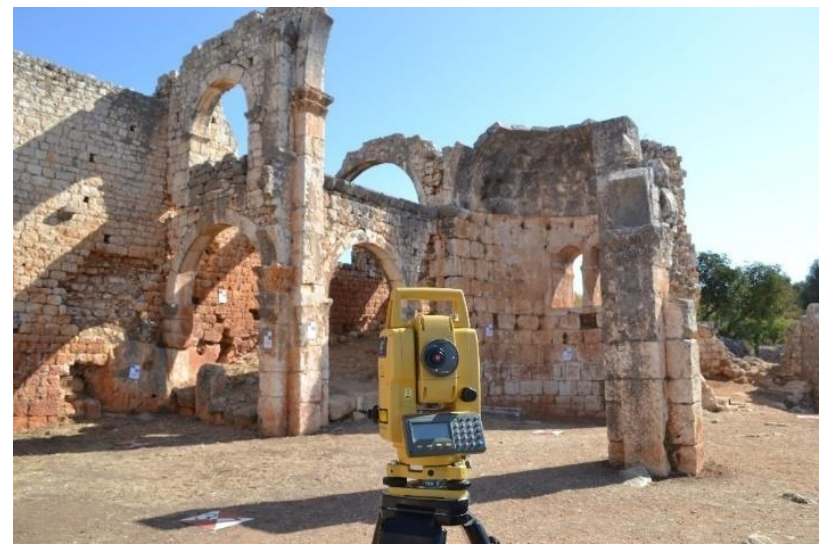

Figure 9. Surveying with Topcon GPT 3007 


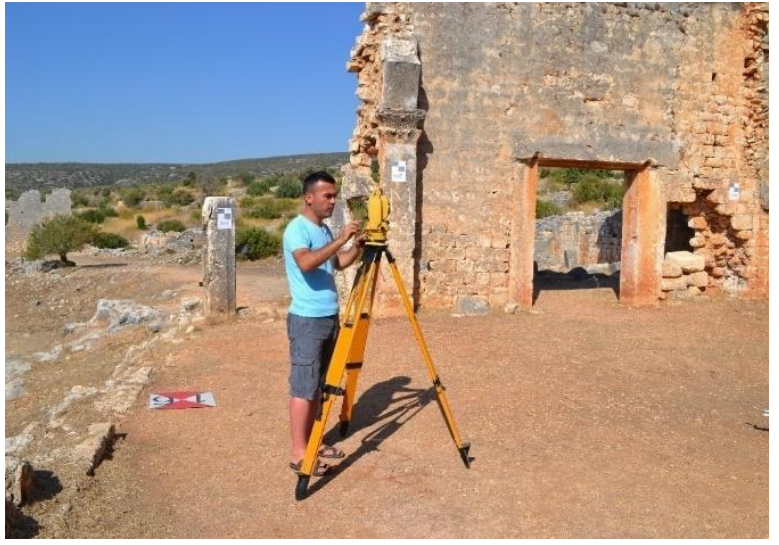

Figure 10. Measuring point operations, and UAV Ground Control Points overview

After measurement and rectification process, UAV flight madefinal checks have been completed (Figure 11-1213).

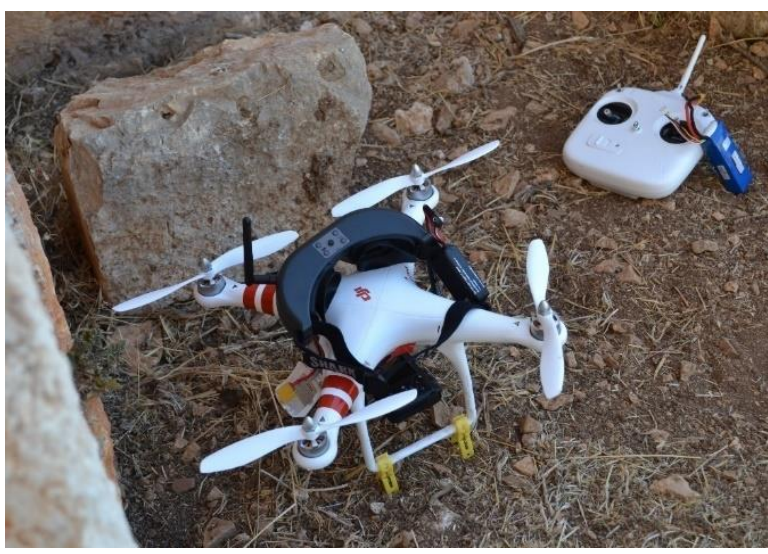

Figure 11. UAV, FPV control and image transfer system

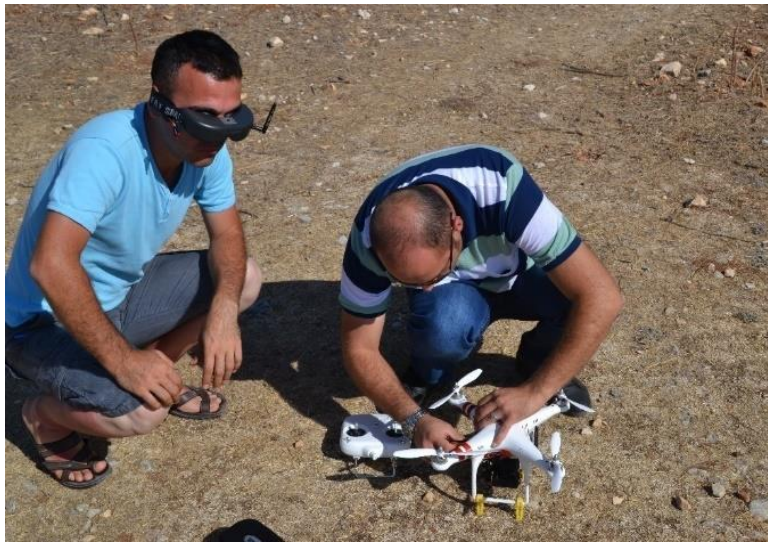

Figure 12. performed the final pre-flight checks

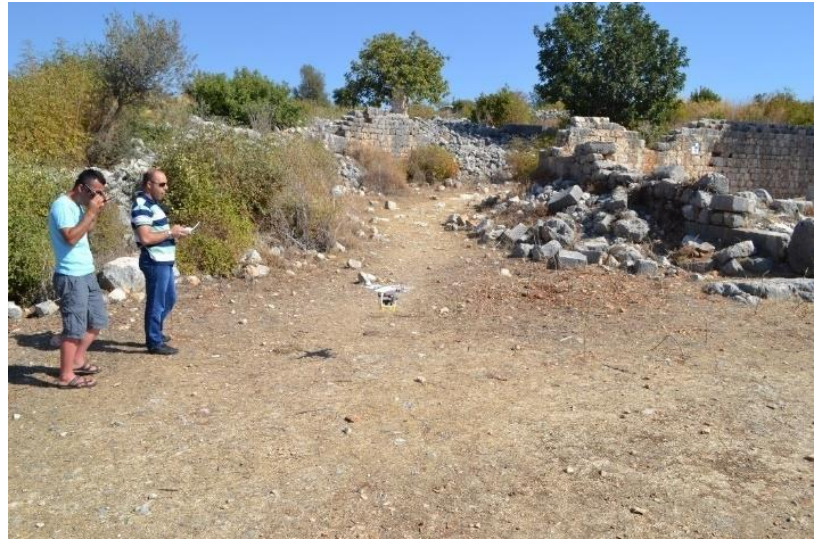

Figure 13. Flying with UAV

After the flight the UAV, the aerial photography work has been completed. Aerial photographs obtained is exemplified below (Figure 14-15).

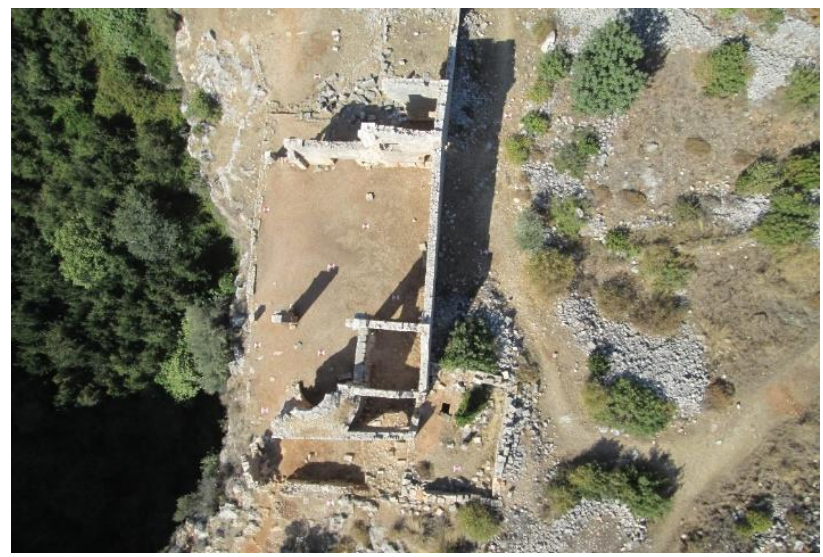

Figure 14.Taken photograph with UAV

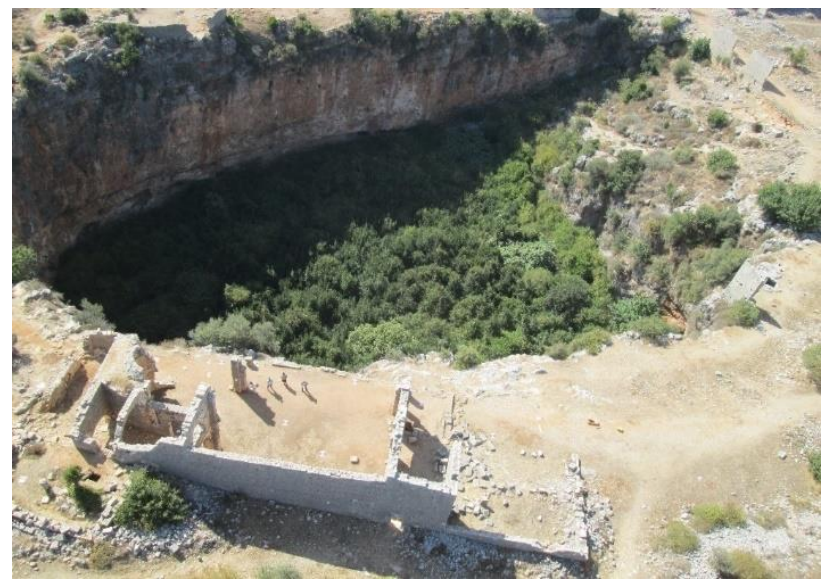

Figure 15.Taken photograph with UAV

After this process is completed, work has started on the office using data obtained.. 
International Journal of Engineering and Geosciences (IJEG), Vol; 1; , Issue; 01, pp. 1-7, December, 2016,

\subsection{Office work}

The coordinates of the traverse used for field measurement is shown in Table 1.

Table 1. traverse coordinates

\begin{tabular}{|l|c|c|c|}
\hline N.N. & Y & X & $Z$ \\
\hline P.1 & 1000.000 & 1000.000 & 1000.000 \\
\hline P.2 & 1000.000 & 1021.225 & 1001.583 \\
\hline P.3 & 1035.587 & 1027.236 & 1005.679 \\
\hline P.4 & 1052.584 & 1014.728 & 1002.668 \\
\hline P.5 & 1026.608 & 1007.357 & 1001.568 \\
\hline P.6 & 1028.650 & 1019.729 & 1001.710 \\
\hline
\end{tabular}

Photos taken from the ground, and obtained from the UAV photos was combined in Photomodeler photogrammetry software and adjustedand made ready for drawing (Figure 16).

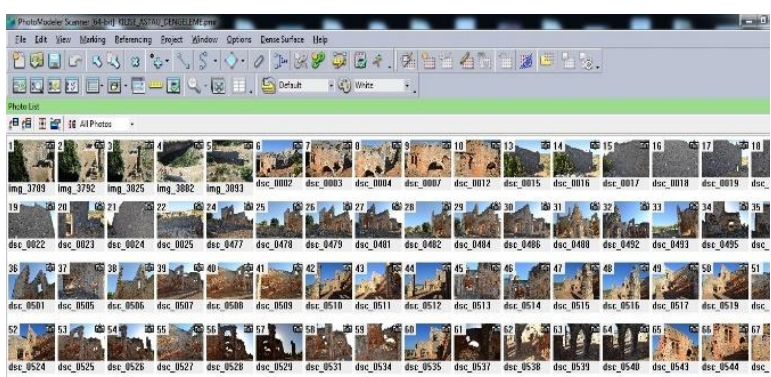

Figure 16. Regulation of photographs obtained in the field and to be ready drawings

3D drawing of the church through adjusted images is completed (Figure 17).

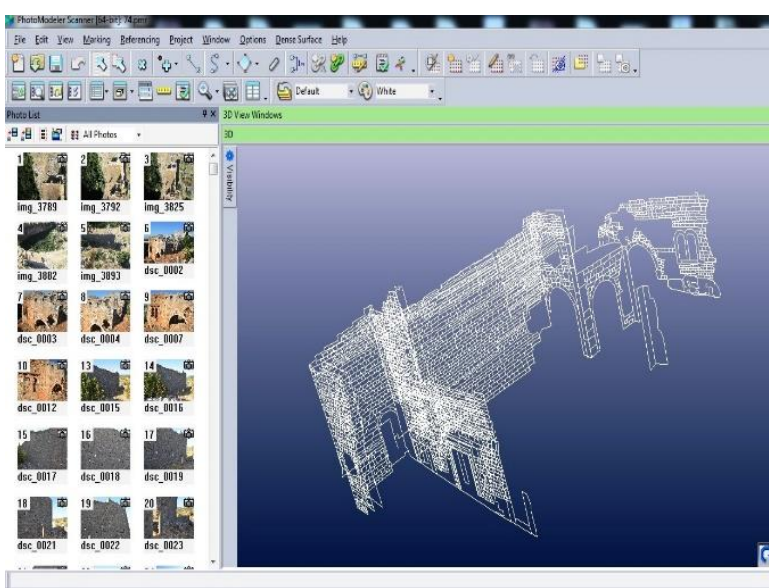

Figure 17. 3D drawing of church
After the drawing, the sensitivity study was conducted on thirty points determined on the church. Coordinates obtained from the land of this point, been accepted as absolute coordinates. The coordinates of the reference point on the adjusted images, obtained through photogrammetry software and compared with terrain coordinates.

Point position accuracy of points $\mathrm{mxyz}=2.1 \mathrm{~cm}$ were found (Table 2).

\section{RESULTS}

Especially in the field of architecture photogrammetry, UAV usage began to hold an important place, increasingly widespread, providing significant advantages in terms of cost time, and effort. for users. In order to protect the world heritage of cultural heritage, with the help of UAV Aerial photographs taken, the measurement obtained

-sufficient accuracy as in,

-can be used as a base to work from different professional disciplines,

-UAVs can be used for photogrammetric anywhere near heights

It concluded has been reached.

For documenting the historical and cultural heritage, the use of close range photogrammetry together with the $\mathrm{UAV}$ is considered to give a new impetus to the work done in this area.

In addition, this model of UAV 's help made using photogrammetric techniques, photographing opportunities increase, and with reason, allows documentation to be more comprehensive and realistic (Toprak AS, 2014) 
International Journal of Engineering and Geosciences (IJEG),

Vol; 1; , Issue; 01, pp. 1-7, December, 2016,

Table 2. Comparison of point coordinates and differences

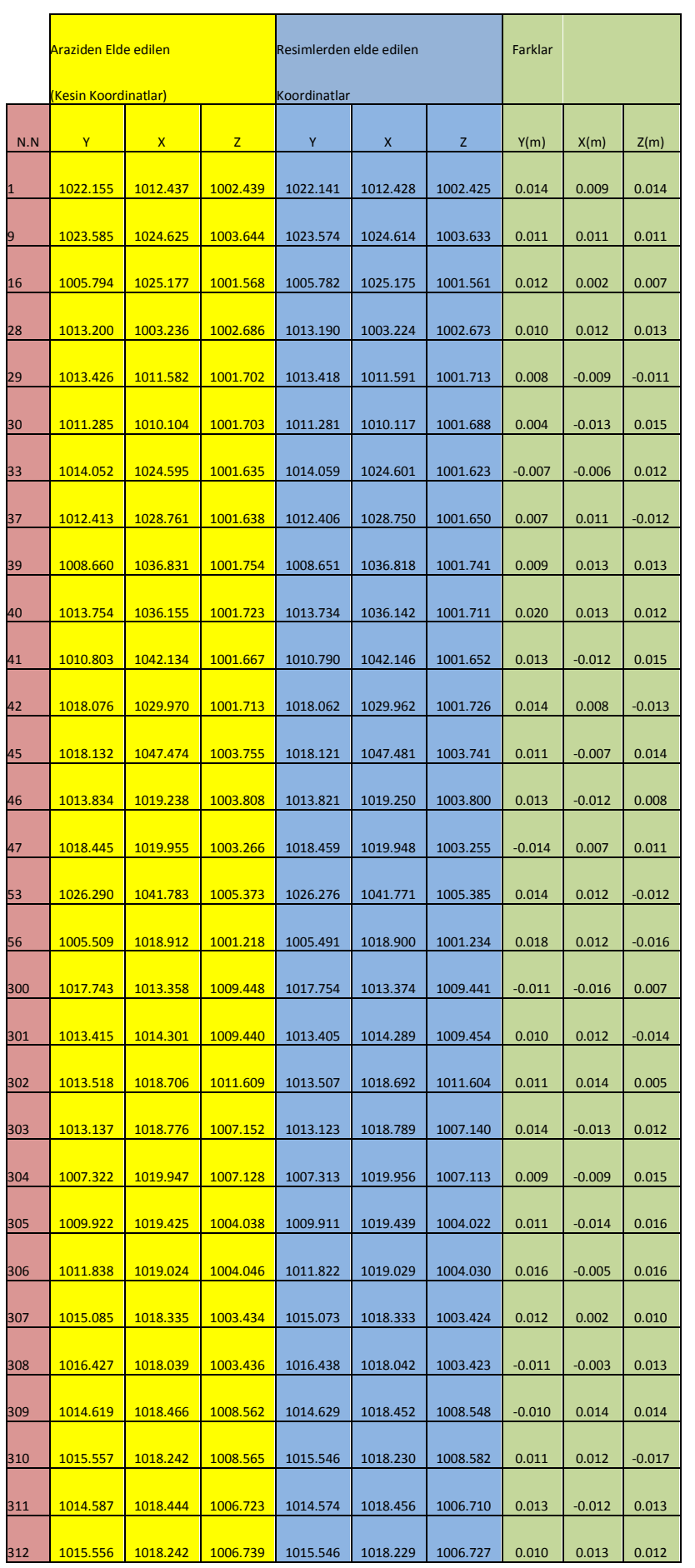

\begin{tabular}{|c|c|c|c|c|c|}
\hline $\mathrm{Vy}(\mathrm{cm})$ & $V_{x}(\mathbf{c m})$ & $\mathrm{Vz}(\mathbf{c m})$ & $\mathbf{V y} \mathbf{y} \mathbf{y}(\mathrm{cm})$ & $\mathbf{V} \mathbf{x} \mathbf{V} \mathbf{x}(\mathbf{c m})$ & $\operatorname{VzVz}(\mathbf{c m})$ \\
\hline 1.4 & 0.9 & 1.4 & 2.0 & 0.8 & 2.0 \\
\hline 1.1 & 1.1 & 1.1 & 1.2 & 1.2 & 1.2 \\
\hline 1.2 & 0.2 & 0.7 & 1.4 & 0.0 & 0.5 \\
\hline 1.0 & 1.2 & 1.3 & 1.0 & 1.4 & 1.7 \\
\hline 0.8 & -0.9 & -1.1 & 0.6 & 0.8 & 1.2 \\
\hline 0.4 & -1.3 & 1.5 & 0.2 & 1.7 & 2.2 \\
\hline-0.7 & -0.6 & 1.2 & 0.5 & 0.4 & 1.4 \\
\hline 0.7 & 1.1 & -1.2 & 0.5 & 1.2 & 1.4 \\
\hline 0.9 & 1.3 & 1.3 & 0.8 & 1.7 & 1.7 \\
\hline 2.0 & 1.3 & 1.2 & 4.0 & 1.7 & 1.4 \\
\hline 1.3 & -1.2 & 1.5 & 1.7 & 1.4 & 2.2 \\
\hline 1.4 & 0.8 & -1.3 & 2.0 & 0.6 & 1.7 \\
\hline 1.1 & -0.7 & 1.4 & 1.2 & 0.5 & 2.0 \\
\hline 1.3 & -1.2 & 0.8 & 1.7 & 1.4 & 0.6 \\
\hline-1.4 & 0.7 & 1.1 & 2.0 & 0.5 & 1.2 \\
\hline 1.4 & 1.2 & -1.2 & 2.0 & 1.4 & 1.4 \\
\hline 1.8 & 1.2 & -1.6 & 3.2 & 1.4 & 2.6 \\
\hline-1.1 & -1.6 & 0.7 & 1.2 & 2.6 & 0.5 \\
\hline 1.0 & 1.2 & -1.4 & 1.0 & 1.4 & 2.0 \\
\hline 1.1 & 1.4 & 0.5 & 1.2 & 2.0 & 0.2 \\
\hline 1.4 & -1.3 & 1.2 & 2.0 & 1.7 & 1.4 \\
\hline 0.9 & -0.9 & 1.5 & 0.8 & 0.8 & 2.2 \\
\hline 1.1 & -1.4 & 1.6 & 1.2 & 2.0 & 2.6 \\
\hline 1.6 & -0.5 & 1.6 & 2.6 & 0.3 & 2.6 \\
\hline 1.2 & 0.2 & 1.0 & 1.4 & 0.0 & 1.0 \\
\hline-1.1 & -0.3 & 1.3 & 1.2 & 0.1 & 1.7 \\
\hline-1.0 & 1.4 & 1.4 & 1.0 & 2.0 & 2.0 \\
\hline 1.1 & 1.2 & -1.7 & 1.2 & 1.4 & 2.9 \\
\hline 1.3 & -1.2 & 1.3 & 1.7 & 1.4 & 1.7 \\
\hline 1.0 & 1.3 & 1.2 & 1.0 & 1.7 & 1.4 \\
\hline & & {$[\mathrm{VV}]=$} & 43.4 & 35.7 & 48.7 \\
\hline
\end{tabular}

$m= \pm \sqrt{\frac{[v \cdot v]}{n}}$

1.1

1.3

mxyz =

2.1 


\section{REFERENCES}

Avdan, U., Gülşen, F. F., Ergincan, F. veÇömert, R. (2014). Arkeolojik Alanlarda Taş Planlarının Çıkarılmasında İnsansız Hava Araçlarının Kullanılması (AnavarzaÖrneği). Mühendislik Ölçmeleri Sempozyumu, 15-17 Ekim 2014, HititÜniversitesi, Çorum.

Eisenbeiss, H., 2009, “UAV Photogrammetry” Doctor of Sciences.

Eroğlu O., 2013, "İnsansız Hava Araçlarında Arazi Verilerine Dayalı UçuşYönü Sınırlamasız Konumlandırma Sistemi Benzetim Çalışması" YüksekLisansTezi.
UlviA.,2015, Metrik Olmayan Dijital Kameraların Hava Fotogrametrisinde Yakın Resim Çalışmalarda (Yere Yakın Yüksekliklerde) Kullanılabilirliği Üzerine Bir Çalışma", DoktoraTezi

Toprak A.S.,2014, "Fotogrametrik Tekniklerin İnsansız Hava Araçları İle Mühendislik Projelerinde Kullanılabilirliğinin Araştırılması” Yüksek LisansTezi.

Copyright (C) International Journal of Engineering and Geosciences (IJEG). All rights reserved, including the making of copies unless permission is obtained from the copyright proprietors. 